\title{
Editorial: Exploring Aspects of Genre
}

The discipline of a public theology has frequently shown its concern for audience, issues and objectives. In these unfolding times the case could be made for it to learn from the widening range of discourse surrounding the Anthropocene. That term itself has been taken from the field of geology-and, in particular, stratigraphy. Its employment has widened, though, to include the social sciences as well as, rather perhaps more urgently, an Earth system science. These manifold disciplines mediate the concerns of the Anthropocene through a diversity of genres ranging from the complex scientific reports and projections through to the philosophy of a dark ecology, popular music, novels, poetry and a remaking of history to include deep time. Now and then there is both an attempt made to reclaim a narrower understanding of what constitutes the Anthropocene-but the diversity of genre and a holding fast to the naming of Anthropocene in a range of disciplinary areas, nevertheless, remains.

In this edition of the journal Darren Cronshaw breaks new ground. His reading of a public theology is expressed on this occasion via the dystopian literature and movie franchise of The Hunger Games. An even tighter definition of genre is one of young adult fiction / science fiction. Its apparent capacity to address contemporary signs of the times resonates with the recent emergence of how 'cli-fi' makes accessible likely situations arising out of the climate emergency. What constitutes a critique of the inequities of a civil society is examined against a background of a post-apocalyptic world of ecological degradation, border control, human rights and the politics of fear. Cronshaw's interpretative comments allow for further discussions on timely matters to do with gender and racism. This choice of genre enables Cronshaw to slant a public theology towards the imagination and energy of a younger audienceand thus render the possibility of the discipline being subject to generational criticism. It also lends itself to a call to public action for those who belong to a generation of younger adults who might otherwise succumb to anomie and disaffection from personal agency and the politics and practices of a common good.

Cronshaw's evident preference for a social activism is consistent with those who favour an empirical research methodology and its consequence 
for praxis. Joseph Goh, Kristine Meneses and Donald Messer traverse familiar discussions surrounding the response of the churches to do with those who are lesbian, gay, bisexual, transgender and those living with HIV. The rhetoric around the image of God, a common humanity, the basileia teaching of Jesus and the prospect of an inclusive church are well-rehearsed around the globe. What sets their work apart is the location of this theme. They are writing out of the experience of the Philippines and Singapore at a time when Taiwan is the only country in Asia that has legalized same sex marriage. In many nonwestern cultures issues of sexuality are not so easily carried out in public. Simply to do so-and thereby render what is private public - is an act of courage. For the sake of an authentic voice the authors draw upon 'elite interviews' conducted with three 'community leader-practitioners' at the cutting edge of this struggle.

Reading an article like the one above is a telling reminder of how matters of a civil society reflect the localized situation. Some years ago now Michael Welker noted how there is a global imbalance in the availability and accessibility of theological ideas and literature from one part of the world to another. The way in which a particular issue of public concern is addressed and the genre employed is not necessarily the same. Sometimes the raft of theoretical thinkers a particular author draws upon might not be the most avant-garde in the field - they are nevertheless available and have a currency in the context under scrutiny.

That is the case with the work of Benyamin Intan whose writing on a public theology and the Pancasila-state in Indonesia draws upon the earlier works of Jürgen Habermas, John Rawls and José Casanova. The other side to this coin is that Intan places their insights alongside those of fellow Indonesian scholars: that should not come as a surprise but this cross-fertilization of ideas to do with a public theology across such very different continents is seldom replicated in the western academy.

Both Intan and Ulrich Schmiedel are dealing with what constitutes a civil society and the relationship between politics and religion. In Intan's case religion is a generic category; the public theology in which he engages is performed in a Muslim-majority and religiously plural society. The focus of his enquiry fastens upon how the vision of Pancasila has been diminished through the work of the Ministry of Religion and its failure to check the growth in religious violence. In its ideal form and practice the five principles upon which Indonesian democracy is established should encourage a cooperative approach among religions for the sake of the public good and a civil society. 
Schmiedel's enquiry into how religion can be co-opted into the service of the state and provoke an uncivil society depends upon a reading and interpretation of a foundational symbol. Writers as diverse as Frances Young and Mona Siddiqui are well-aware that the Christian sign of the cross is multivalent and not self-evident in meaning. Set within what Schmiedel designates as a postmigrant context the symbol of the cross is proffered as a vehicle of Bavarian identity and a means of courting populism. Schmiedel's interest is not in a theological hermeneutic of the cross per se: it lies rather in the political usage of the symbol and the need to counter is uncivil deployment. In an ecumenical mode the responses made by Heinrich Bedford-Strohm (Protestant) and Reinhard Marx (Roman Catholic) critique this provocative use of the cross. The controversy itself enables Schmiedel to revisit the distinctions that are made between a civil religion and a public faith. In the process Schmiedel is able to argue the rather timely case for public theologies 'in the plural' and how such theologies can play an important role in the construction of a civil society, especially when populism is abounding.

By way of contrast Frederike van Oorschot directs attention onto a gap she discerns with reference to how public theologians 'bring their theology into the practice of the church'. For this purpose she makes use of a typology to discuss the various ways in which words like theology, public and the church intersect with one another. There is a relative turn to an ecclesiology at a point in time when many articles in the field of a public theology are on themes to do with refugees, asylum-seekers, climate change and the role of non-governmental organizations. This shift in genre-to ecclesiology and typology (via four different categories) - leads to a consideration of the ways in which liturgy and formation for ministry perform a vital function in the moral formation of an ecclesial community than can address public issues in a mix of explicit and implicit ways.

In the service of an explicit feminist public theology Juliana Claasens seeks to build upon the work of others who have gone before her-most notably, Denise Ackerman. The occasion for her desire to 'imagine the world to be otherwise' lies in the need to address constructively 'the reality of the deep wounds and the scars caused by racism, sexism, xenophobia, and homophobia, which, if left unattended, may fester and return with a vengeance'. Claasens makes a more sustained use of Scripture as a genre of public theology than is often the case. Through a reading of the book of Jeremiah, Claasens is able to express lament and a naming of injustice while seeking to transcend the violence that leads to such through values of 'compassion, justice, resistance and resilience'. 
This broadening of resources and genre is matched with a globally widening engagement with public theology. The presenting issues often bear great resemblance from one setting to another. How a public theology is then constructed and sets about being bilingual with regards its particular audience can differ markedly.

Clive Pearson

Editor-in-Chief 